\title{
ДІАГНОСТИКА І ЛІКУВАЛЬНІ ТРАНСПАПІЛЯРНІ ВТРУЧАННЯ У ХВОРИХ 3 ПРИВОДУ ПОРТАЛЬНОЇ БІЛІОПАТІЇ
}

\author{
В. І. Коломійцев \\ Львівський національний медичний університет імені Данила Галицького

\section{DIAGNOSIS AND TREATMENT, USING TRANSPAPILLARY INTERVENTIONS, IN PATIENTS, SUFFERING PORTAL BILIOPATHY}

\author{
V. I. Kolomiytsev \\ Lviv National Medical University named after Danylo Galytskyi
}

\section{Peфpepat}

Проаналізовані результати мініінвазивних ендоскопічних втручань у 31 хворого з приводу портальної біліопатії (ПБ). У 7 (23\%) хворих ПБ виникла на тлі тромбозу ворітної вени (ВВ), у 19 (61\%) - виявлені клінічні ознаки, пов'язані з ураженням жовчних проток: холедохолітіазу (у 16\%), стриктури (у 35\%), папілостенозу, що супроводжувалося гіпербілірубінемією, жовтяницею, холангітом. Діагностичний комплекс включав ультразвукове дослідження (УЗД) з допплерографією, контрастно-підсилену комп'ютерну томографію (КТ), магніторезонансну холангіопанкреатикографрію (МРХПГ), діагностичну та лікувальну ендоскопічну ретроградну холангіографію (ЕРХГ) з папілосфрінктеротомією (ЕПСТ), літоекстракцією, ендобіліарним стентуванням. Ендоскопічні транспапілярні втручання, не усуваючи основну патогенетичну причину ПБ - портальну гіпертензію (ПГ), дозволяють у більшості хворих вирішити проблеми біліарної гіпертензії.

Ключові слова: портальна гіпертензія; портальна біліопатія; ендоскопічна ретроградна холангіографія; транспапілярні втручання. Abstract

Results of miniinvasive endoscopic interventions in 31 patients, suffering portal biliopathy, were analyzed. In 7 (23\%) patientsa portal biliopathy have occurred on background of the portal vein thrombosis, and in $19(61 \%)$ - clinical signs were revealed, connected with the biliary ducts affection: choledocholithiasis (in 16\%), stricture (in 35\%), papillostenosis, coexistent with hyperbilirubinemia, jaundice, cholangitis. Diagnostic complex included ultrasonographic investigations with dopplerography, contrast-enhanced computeric tomography, magnet-resonance cholangiopancreaticography, diagnostic and treatment endoscopic retrograde cholangiography with papillosphincterotomy, lithoextraction, endobiliary stenting. Endoscopic transpapillary interventions, not eliminating the main pathogenetic cause of portal biliopathy-portal hypertension -permit to solve the biliary hypertension problem in majority of patients.

Keywords: portal hypertension; portal biliopathy; endoscopic retrograde cholangiography; transpapillary interventions.

Основною причиною виникнення ПГ вважають цироз печінки (ЦП), проте, у 3- 40\% хворих ПГ первинно виникає як наслідок тромбозу ВВ, фіброзу печінки, аномалії судин тощо $[1,2]$.

При оклюзії ВВ швидко виникає компенсаторне розширення розташованих у гепатодуоденальній зв'язці вен і сплетень- епіхоледохеального венозного сплетення Саїнта (Saint's plexus) і парахоледохеальних вен Петрена (Petren). Розвиток нових колатералей і початок реканалізації обтурованої ВВ сприяють відновленню основного шляху постачання печінки кров'ю- кровотоку в системі ВВ [3]. Крім значного розширення вен гепатодуоденальної зв'язки з формуванням вариксів, відбувається кавернозна трансформація ВВ, що зумовлюе компресію жовчних проток і протоки підшлункової залози $[1,4]$ з відповідними клінічними проявами.
Симптомокомплекс, що виникає за такої ситуації, в літературі названий «псевдосклерозуючим холангітом» (pseudosclerosing cholangitis), «холангіопатією, пов'язаною $з$ ПГ» (cholangiopathy associated with portal hypertension), «Ознакою псевдохолангіоцелюлярної карциноми» (pseudocholangiocellular carcinoma sign), «пов'язаною 3 каверномами портальною холангіопаTiєю» (portal cavernoma-associated cholangiopathy), «портальною дуктопатією» (portal ductopathy), «портальною гіпертензивною біліопатією» (portal hypertensive biliopathy), проте, найчастіше використовують термін «портальна біліопатія» (portal biliopathy) [1, 2, 5 - 7]. Всі наведені назви синдрому вказують на наявність змін біліарної системи 3 порушенням або, на певних фазах, без порушення прохідності жовчних проток. Оскільки захворювання $€$ досить рідкісним, в літературі немає однозначної думки щодо лікувальної тактики, це спонукало нас поділитися власним досвідом.

Метою дослідження було опрацювання діагностичної та лікувальної тактики з використанням мініінвазивних ендоскопічних технологій у хворих з приводу ускладненої ПБ.

\section{МАТЕРІАЛИ I МЕТОДИ ДОСЛІДЖЕННЯ}

За 20 років ми спостерігали 19 хворих 3 клінічно вираженою ПБ віком від 18 до 59 років; переважали чоловіки- 12 (63\%). ПБ виявляли в основному під час обстеження хворих $з$ приводу ПГ. Так, 345 пацієнтів за наявності жовчнокам'яної хвороби на тлі ПГ з ознаками біліарної обструкції за даними лікувальної ЕРХПГ у 9 (20\%) виявлені зміни позапечінкових жовчних проток, характерні для ПБ, у 4 з них саме ПБ була причиною біліарної обструкціï. Ще у 10 хворих при ПГ і ознаках 
безкам'яної обтураційної жовтяниці під час обстеження виявлена ПБ як етіологічний чинник біліарної гіпертензіі. У 12 пацієнтів відзначений асимптомний перебіг захворювання, припущення про характерні зміни жовчних проток виникло під час УЗД, підтверджене за даними МРХПГ та/або ЕРХПГ.

Всім хворим, крім лабораторних досліджень, проведене УЗД з ретельним обстеженням органів гепатопанкреатобіліарної зони і визначенням за даними допплерографії параметрів портальної, печінкової і спланхнічної гемодинаміки. У 5 (16\%) хворих додатково проведена КТ з контрастуванням, у 6 (19\%)МРХПГ. Для виявлення і визначення ступеня розширення вен стравоходу, портальної гастропатії та ектопованих вариксів в усіх хворих проведена езофагогастродуоденоскопія, в 11 (35\%)- ще рентгеноконтрастне дослідження травного каналу.

Тяжкість перебігу ЦП визначали за критеріями Child-Pugh, ступінь печінкової недостатності оцінювали за шкалами Glasgow Coma Scale (GCS) та West Haven Criteria (WHC).

Отримані результати аналізували за допомогою статистичної програми SPSS 11.5 for Windows. Для порівняння параметричних показників використовували t-тест Ст'юдента, непараметричних- U-тест Манна Уітні, відносних $-\chi^{2}-$ тест.

\section{РЕЗУЛЬТАТИ \\ ТА ÏХ ОБГОВОРЕННЯ}

В усіх хворих виявлена ПГ, у 25 за даними біохімічних, імунологічних, вірусологічних і гістологічних (пункційна та/або інтраопераційна біопсія печінки) досліджень встановлений діагноз ЦП, що ускладнився розширенням вен стравоходу- у 16 (52\%), набряково-асцитичним синдромом- у 4 (13\%), спленомегалією- у 8 (26\%), гіперспленізмому 8 (26\%). Відповідно до класифікаціï Child-Pugh, ЦП у стадії компенсації (А) встановлений у 20 (80\%) хворих, субкомпенсації (В)- у 4 (16\%), декомпенсації (С)- в 1 (4\%). За критеріями WHC, печінкова енцефалопатія I ступеня виявлена при госпіталізації у 13 (42\%) хворих, II ступеняу 3 (10\%), III ступеня - в 1 (3\%).

За даними літератури, ПБ найчастіше пов'язана з ПГ на тлі тромбозу ВВ $[1,5,6,8]$. В нашому дослідженні етіологічними чинниками ПГ і ЦП були алкогольний гепатитв 11 (35\%) хворих, вірусний гепатит- у 10 (32\%), вроджена аномалія в ділянці гепатодуоденальної зв'язки- у 3 (10\%), і лише у 7 (23\%) хворих виявлена оклюзія (ймовірно, тромбоз) ВВ. Причиною тромбозу

Порівняння проявів симптомної та асимптомної ПБ

\begin{tabular}{|c|c|c|}
\hline Ознака & $\begin{array}{c}\text { Симптомна ПБ } \\
(n=19)\end{array}$ & $\begin{array}{c}\text { Асимптомна ПБ } \\
(n=12)\end{array}$ \\
\hline Тромбоз ВВ & 6 & 1 \\
\hline Цироз печінки & 17 & 8 \\
\hline Спленомегалія & $14^{*}$ & 1 \\
\hline Жовчнокам'яна хвороба & 9 & 3 \\
\hline Холедохолітіаз & 5* & - \\
\hline Холангіт & 7* & - \\
\hline Загальний білірубін сироватки крові, мкмоль/л ${ }^{\Delta}$ & $\begin{array}{c}75 \\
(70 ; 105)^{*}\end{array}$ & $\begin{array}{c}20 \\
(15 ; 25)\end{array}$ \\
\hline Прямий білірубін сироватки крові, мкмоль/л ${ }^{\Delta}$ & $\begin{array}{c}60 \\
(55 ; 80)^{*}\end{array}$ & $\begin{array}{c}18 \\
(14 ; 22)\end{array}$ \\
\hline 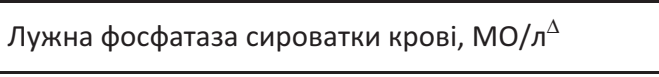 & $\begin{array}{c}180 \\
(150 ; 250)^{*} \\
\end{array}$ & $\begin{array}{c}100 \\
(85 ; 130) \\
\end{array}$ \\
\hline Кровотеча з вен стравоходу & 3 & - \\
\hline Ектоповані варикси & 2 & - \\
\hline Допплерографія - наявність каверноми & $7^{*}$ & 1 \\
\hline ЕРХГ- стеноз сосочка & 3 & 2 \\
\hline ЕРХГ - локальна дилатація СЖП & 11 & 5 \\
\hline ЕРХГ - стриктура СЖП & $10 *$ & 1 \\
\hline ЕРХГ- зміни печінкових проток & 4 & 3 \\
\hline
\end{tabular}

Примітка. ${ }^{\Delta}$ - медіана та 1 і 3 квартилі; * - різниця показників достовірна порівняно з такими за асимптомної ПБ ( $<<0,05-0,01)$.
ВВ у 4 хворих був гострий або хронічний панкреатит, у 2- травма гепатодуоденальної зв'язки, в 1 - інвазія пухлиною. У патогенезі ПБ виділяють два основні чинники. 3 одного боку, тиск на стінку спільної жовчної протоки (СЖП) з формуванням нерівностей iї контуру безпосередньО створюють значно розширені вени епіхоледохеального венозного сплетення і парахоледохеальні вени, що особливо виражено при тромбозі ВВ $[1,5] .3$ іншого боку, на формування змін стінок жовчних проток впливає розростання у них сполучної тканини внаслідок склерозу та некрозу судин і локальної ішеміі, утворення колагену та фіброзу тканин. Внаслідок утворення фіброзної тканини виникають різної протяжності ділянки стриктури проток, між ними з'являються зони дилатації, що загалом порушує пасаж жовчі у протоках, спричиняє холестаз [9, 10]. Додатковим патогенетичним чинником є приєднання холангіту, що зумовлює рубцювання й утворення стриктури СЖП [5].

Клінічними проявами ПБ були ознаки, пов'язані з синдромом ПГ (асцит, портальна гастропатія, варикси стравоходу та шлунка 3 виникненням кровотечі, енцефалопатія, гіперспленізм, коагулопатія тощо), і симптоми біліарної патології (див. таблицю). У 12 (39\%) пацієнтів захворювання виявлене випадково під час УЗД печінки і жовчних проток.

Характерними ознаками ПБ були симптоми холестазу внаслідок обструкції жовчних проток, що супроводжувалось гіпербілірубінемією, жовтяницею, свербінням шкіри, періодичним болем у правій підребровій ділянці, підвищенням температури тіла. ПГ часто супроводжується жовчнокам'яною хворобою [7]. В нашому дослідженні у 12 (39\%) хворих виявлений холелітіаз, у 5 (16\%)- холедохолітіаз. В 11 (35\%) хворих біліарна гіпертензія була пов'язана 3 наявністю стриктури СЖП, у 5 (16\%) з них - це було ішемічно-фіброзне ураження стінки протоки, у 6 (19\%)наслідок компресії судин і каверноми. У 6 (19\%) хворих виявлені симптоми гострого або хронічного панкреатиту, пухлини тіла підшлункової залози. Виникнення ознобу при болю в надчеревній ділянці у 7 (23\%) хворих було зумовлене холангітом, 
в одного хворого виявлені сепсис та абсцеси печінки.

Обстеження пацієнтів розпочинали з УзД в режимі сірої шкали. Метод дозволив виявити дилатацію та аномалії СЖП. У 4 хворих виявлений холедохолітіаз. Проте, метод має недоліки: в ехо-щільній печінці складно виявити жовчні протоки, а пошук СЖП в структурах гепатодуоденальної зв'язки значно ускладнений при тромбозі ВВ (рис. 1) і наявності великої кількості розширених вен. Кольорова допплерографія допомагає підтвердити наявність множинних звивистих вен у зв'язці, визначити у них кровоток, диференціювати СЖП, виявити зміни у іiі стінці і просвіті. Це допомогло в 1 хворого виявити холедохолітіаз, у 4 - підтвердити наявність стриктури, у 2 хворих- діагностувати варикси стінки СЖП. Більш точну інформацію за потреби можна отримати за даними ендосонографії (особливо 3 допплерографією) або неінвазивної контрастно-підсиленої КТ в режимі ангіографії, МРХПГ [6, 7, 10], що здійснено відповідно у 5 і 6 хворих.

Особливе місце у діагностиці й лікуванні ПБ посідає діагностична та лікувальна ЕРХПГ, яку застосували у 28 хворих. Показанням до проведення ЕРХПГ була наявність лабораторних та/або УЗД ознак біліарної гіпертензії (у 25 хворих). 3 діагностичною метою ЕРХПГ проведена у хворих при припущенні про наявність ПБ лише за відсутності можливості проведення МРХПГ. При виконанні ЕРХПГ у хворих з ПБ слід пам'ятати про деякі застереження. Наявність ПГ спричинила розширення вен стравоходу та кардіального відділу шлунка у 16 (52\%) хворих, у 2 - виявлені ектоповані варикси у дванадцятипалій кишці (ДПК), пошкодження цих вен і вариксів під час ЕРХПГ небажане через загрозу виникнення тяжкої кровотечі [11]. У 5 (16\%) хворих до втручання виявлені порушення гемокоагуляції, що обмежувало можливості проведення адекватної ЕПСТ з переважанням дилатаційних методів доступу до жовчних проток (при балонній дилатації великого сосочка ДПК- ВС ДПК ризик виникнення кровотечі менший). Інструментальну ревізію жовчних проток та літоекстракцію слід здійснювати максимально обережно, бажано, з використанням не
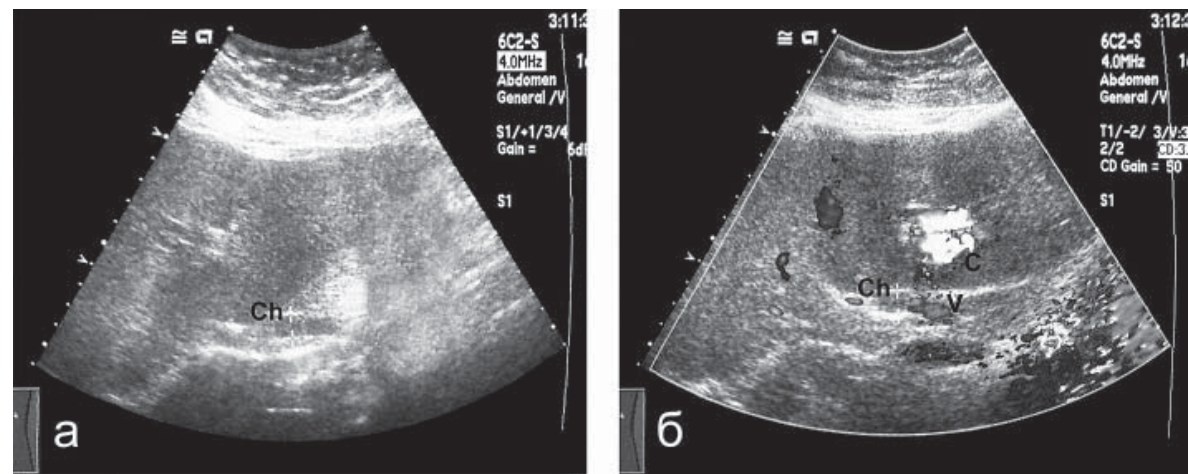

Pис. 1.

УзД зони гепатодуоденальної зв'язки при ПБ в режимі “сірої шкали” (а) та з використанням кольорової допплерографії (б). ВВ тромбована. Ch- СЖП;

V- варикс, що стискає СЖП; С- кавернома, що не прилягає до СЖП.

кошика, а балонного літоекстрактоpa, особливо якщо за даними кольорової допплерографії виявлені варикси у стінці СЖП [8]. Ми спостерігали двох таких пацієнтів, в одного з них після вдалої літоекстракції виникла гемобілія, допоміжним за такої ситуації виявилося тривале стискання стінки проток і вени дилатаційним балоном. Загалом під час діагностичного етапу ЕРХПГ (рис. 2) виявлено хвилясту деформацію стінки і звужень СЖП в усіх хворих (що підтвердило діагноз ПБ), стриктуру СЖП з порушенням ії прохідності - в 11 (35\%) хворих, локальну дилатацію СЖП-у 16 (52\%), холедохолітіаз- у 5 (16\%), стеноз ВС ДПК- у 5 (16\%). Частота і вид проявів різнилися за симптомної та асимптомної ПБ. Характерним при ПБ за даними ЕРХПГ є необов'язкове та нерівномірне розширення проток вище місця обструкції, відсутність симетричності розширення печінкових проток.

Лікувальний етап ЕРХПГ включав проведення ЕПСТ (у 26 хворих) та/або балонної дилатації ВС ДПК (у 5) 3 подальшою літоекстракцією (у 5), балонною дилатацією стриктури СЖП (у 9), ендобіліарним стентуванням (встановлені 8 пластикових і 2 металевих стентів довжиною 60 110 мм). У 2 хворих 3 приводу хронічного панкреатиту проведено вірсунготомію, в 1 з них - встановлений панкреатичний стент.

Консервативна терапія, проведена у хворих за симптомної ПБ, спрямована, насамперед, на зменшення вираженості ПГ шляхом застосування неселективних бета-блокаторів. 3 метою попередження інфекційних ускладнень застосовували анти-

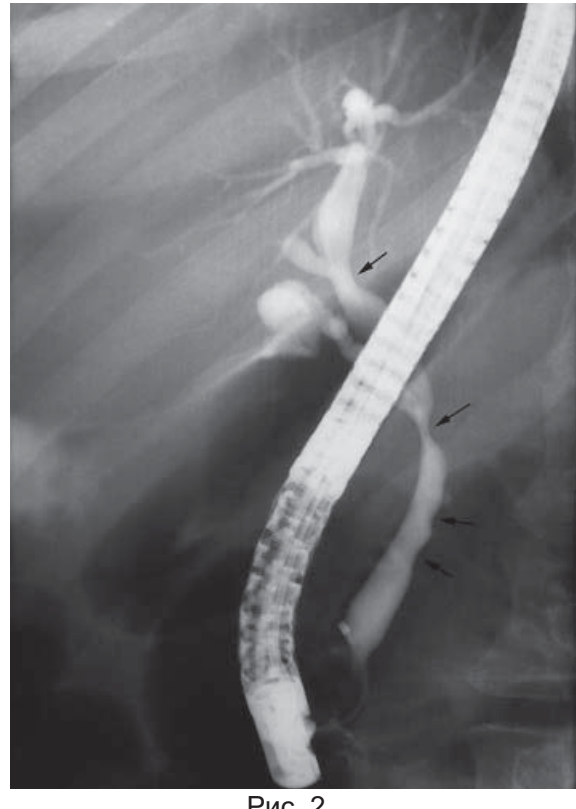

Рис. 2

ЕРХПГ при ПБ.

Стрілками показані місця звуження і компресії вариксами СЖП.

біотики, для профілактики рецидиву парати урсодезоксихолевої кислоти Проводили корекцію порушень коагуляції крові.

\section{ВИСНОВКИ}

1. ПБ у хворих при ПГ може супроводжуватися біліарною обструкцією.

2. Майже у 25\% хворих за симптомної ПБ виявлений холедохолітіa3.

3. Комплексний та виважений підхід до діагностики й лікування хворих $з$ приводу симптомної ПБ з застосуванням ендоскопічних транспапілярних втручань дозволяє за мінімальної частоти ускладнень досягти хороших безпосередніх і віддалених результатів. холедохолітіазу - призначали пре- 


\section{REFERENCES}

1. Bayraktar Y. Portal ductopathy: clinical importance and nomenclature. World J Gastroenterol. 2011;17(11):1410-5. doi: 10.3748/wjg. v17.i11.1410.

2. Dhiman RK, Behera A, Chawla YK, et al. Portal hypertensive biliopathy. Gut. 2007;56(7):1001-8. doi: 10.1136/gut.2006.103606

3. Nichitaylo ME, Ganzhiy VV, Tugushev AS, Andrienko SA. Otsenka pechenochnogo krovotoka pri tsirroze pecheni. Klinichna khirurhiia. 2014;(3):12-5. [In Russian].

4. Bhatia V. Endoscopic retrograde cholangiography in portal cavernoma cholangiopathy - results from different studies and proposal for uniform terminology. J Clin Exp Hepatol. 2014;(4), Suppl 1:37-43. doi: 10.1016/j.jceh.2013.05.013.

5. Garbuzenko DV. Portal'naya biliopatiya. Vrach. 2014;(1):17-20. [In Russian].

6. Chawla Y, Agrawal S. Portal Cavernoma Cholangiopathy- History, Definition and Nomenclature. J Clin Exp Hepatol. 2014;(4), Suppl 1:15-7. doi: 10.1016/j.jceh.2013.04.001
7. Khuroo MS, Rather AA, Khuroo NS, Khuroo MS. Portal biliopathy World J Gastroenterol. 2016;22(35):7973-82. doi: 10.3748/wjg.v22. i35.7973

8. Sharma M, Babu CS, Dhiman RK, Chawla Y. Induced hypotension in the management of acute hemobilia during therapeutic ERCP in a patient with portal biliopathy. Gastrointest Endosc. 2010;72(6):13179.

9. Franceschet I, Zanetto A, Ferrarese A, et al. Therapeutic approaches for portal biliopathy: A systematic review. World J Gastroenterol. 2016;22(45):9909-20. doi: 10.3748/wjg.v22.i45.9909

10. Harmanci O, Bayraktar Y. How can portal vein cavernous transformation cause chronic incomplete biliary obstruction? World J Gastroenterol. 2012;18(26):3375-8. doi: 10.3748/wjg.v18.i26.3375.

11. House T, Webb P, Baarson C. Massive hemorrhage from ectopic duodenal varices: importance of a multidisciplinary approach. Case Rep Gastroenterol. 2017;11(1):36-41. doi: 10.1159/000455184 